Joanna Pierzga

(D) https://orcid.org/0000-0002-1949-0949

Akademia Ignatianum w Krakowie

\title{
Solidarność ironiczna i solidarność dyskursywna. Kilka uwag o miejscu solidarności w filozofii społecznej Richarda Rorty'ego i Jürgena Habermasa
}

(li) https://doi.org/10.15633/9788374389952.05

W tekście tym spróbuję udzielić zwięzłej odpowiedzi na pytanie, jak Jürgen Habermas i Richard Rorty rozumieją solidarność. Przedstawię pokrótce, jakie miejsce solidarność zajmuje $\mathrm{w}$ ich filozofiach oraz jaka relacja zachodzi między ujęciami solidarności obu filozofów. Zacznę od Habermasa, a później przejdę do Rorty'ego.

Habermas podejmuje temat solidarności w Teorii działania komunikacyjnego, w której pojawia się pojęcie integracji społecznej ${ }^{1}$. W przypadku jego filozofii nie można jednak mówić o teorii solidarności, a jej pojęcie jest niejasne $^{2}$. Refleksję Habermasa nad solidarnością przybliża Dariusz Dobrzański Stwierdza on, że koncepcja solidarności u Habermasa jest koncepcją solidarności pozytywnej, która opiera się na empatii, wzajemnym przyjmowaniu ról, udanej socjalizacji w rodzinie oraz dyskursie.

Dobrzański zwraca uwagę, że u Habermasa ważne jest pojęcie socjalizacji ${ }^{4}$. Paradoks kryjący się w tym pojęciu polega na tym, że proces socjalizacji jest indywiduacją i uspołecznianiem zarazem. Model socjalizacji niemieckiego filozofa opiera się na działaniu komunikacyjnym i zbudowany jest w odniesieniu do filozofii społecznej Émile’a Durkheima, psychologii społecznej

1 Zob. J. Habermas, Teoria dziatania komunikacyjnego, t. 1: Racjonalność działania a racjonalność społeczna, tłum. A. M. Kaniowski, Warszawa 1999.

2 Por. D. Dobrzański, Zasada solidarności. Studium z filozofii społecznej, Poznań 2013, s. 193.

3 Por. D. Dobrzański, Zasada solidarności..., dz. cyt., s. 189-253.

4 Por. D. Dobrzański, Zasada solidarności..., dz. cyt., s. 210. 
George'a Herberta Meada i rozwoju moralnego Lawrence'a Kohlberga. Według Habermasa lingwistycznie mediowany proces socjalizacji i konstrukcji indywidualnej historii życia oddaje istotę procesu indywiduacji tożsamości. Jednostka tworzy swą tożsamość podczas socjalizacji, tworząc siebie w porozumieniu z innymi. Intersubiektywność uznania i samorozumienia pomaga jej tworzyć swą indywidualność. Podmiotowość zatem tworzy się dzięki zdolności do mówienia, słuchania i działania.

Zainteresowanie zagadnieniem form solidarności, czyli sposobów integracji społecznej, Habermas zaczerpnął od Durkheima ${ }^{5}$. Niemiecki filozof pojęcie świadomości zbiorowej Durkheima pogłębia o wymiar komunikacyjny. Habermas nazywa podwójnym sukcesem osiągnięcie Durkheima, który opisał sakralne korzenie moralnego autorytetu norm społecznych, dzięki czemu odróżnił reguły techniczne od reguł moralnych i wyjaśnił obowiązywanie tych kategorii. Teoria rozumu komunikacyjnego Habermasa jest odpowiedzią na pytanie Durkheima dotyczące trwałości relacji społecznych jako zsekularyzowanej moralności. Według Habermasa działanie komunikacyjne nie jest dość braną pod uwagę przez Durkheima instancją dokonującą rozdziału energii solidarności społecznej ${ }^{6}$. Modyfikując stanowisko Durkheima, Habermas wprowadza termin „świat życia” zamiast pojęcia świadomości zbiorowej. „Strukturalne zróżnicowanie systemów społecznych” zastępuje u niego natomiast „społeczny podział pracy”7 Habermas stwierdza, że Durkheim transformację od solidarności mechanicznej do organicznej charakteryzuje na trzech płaszczyznach: racjonalizacji obrazów świata, generalizacji norm moralnych i prawnych oraz postępującej indywidualizacji .

Habermas przyjmuje za Maxem Weberem tezę o nowoczesnej racjonalizacji świata życia ${ }^{9}$. Zaznacza, że procesy abstrakcji przedmiotu religii i transcendencji są obszarem racjonalizacji obrazów świata. Jego zdaniem Weber mierzy racjonalizację obrazów świata stopniem, w jaki zostaje przezwyciężone myślenie magiczne ${ }^{10}$.Zracjonalizowany obraz nowoczesnego świata jest zmieniany przez racjonalną naukę, refleksyjne i krytyczne nastawienie wobec tradycji oraz ukierunkowanie na przyszłość. Uniwersalizacja prawa i moralności to

5 Por. D. Dobrzański, Zasada solidarności..., dz. cyt., s. 189.

6 Por. J. Habermas, Teoria dziatania komunikacyjnego, t. 2: Przyczynek do krytyki rozumu funkcjonalnego, tłum. A. M. Kaniowski, Warszawa 2002, s. 105.

7 Por. D. Dobrzański, Zasada solidarności..., dz. cyt., s. 190.

8 Por. J. Habermas, Teoria dziatania komunikacyjnego, t. 2..., dz. cyt., s. 149.

9 Por. D. Dobrzański, Zasada solidarności..., dz. cyt., s. 190.

10 J. Habermas, Teoria dziatania komunikacyjnego, t. 1..., dz. cyt., s. 364. 
zmiana, która ujawnia się przy omawianiu sfery prawa i norm moralnych. Indywidualny zasięg wolności - interpretacja i konieczność racjonalnego uzasadnienia - jest powiększany przez uniwersalizację norm moralnych. Poprzez uniwersalizację prawa dochodzi do jego „odczarowania” ${ }^{11}$. W wymiarze racjonalizacji etycznej Habermas zwraca uwagę na Weberowską obserwację odczarowania w odniesieniu do interakcji między wiernym a Bogiem. „Im bardziej stosunek ten - pisze Habermas - wykształca się w czysto komunikacyjną relację między osobami, między indywiduum, które potrzebuje zbawienia, a pozaświatową instancją zbawczą, która wydaje moralne nakazy, tym ściślej jednostka może systematyzować swe wewnątrzświatowe relacje w abstrakcyjnej optyce moralności, której podporządkowani są albo jedynie wybrani, religijni wirtuozi, albo w jednakowy sposób wszyscy wierni”12.

Większość teoretyków nowoczesności za jedne z najistotniejszych przejawów trzeciej płaszczyzny przejścia od solidarności mechanicznej do organicznej uznaje proces indywidualizacji, a węziej - osobowej indywiduacji ${ }^{13}$. Induwiduacja jest technicznym terminem psychologii rozwojowej oznaczającym rozwój psychologiczny jednostki, którego celem ostatecznym ma być konstrukcja „jaźni”, czyli tożsamości. W filozofii dyskusję nad indywiduacją rozpoczęło prawdopodobnie wprowadzone przez Dunsa Szkota pojęcie formy jednostkowej (haecceitas) czyniącej konkretne indywiduum określoną rzeczą lub osobą. Dla Habermasa znaczenie pojęcia indywiduum powinno być objaśniane w terminach etycznego samorozumienia „ja” w odniesieniu do „ty”14. Indywidualność może zostać osiągnięta jedynie przez kogoś, kto wie, kim jest i kim chce być. Indywiduacja wiedzie do autonomii podmiotu. Autonomia ta rozumiana jako możliwość refleksyjnego odniesienia podmiotu do siebie jest charakterystyczną cechą nowych form solidarności ${ }^{15}$. Świadomie konstruowanej autonomii nie bronią już tradycyjne wartości. Dawna integracja przez wiarę została zastąpiona przez kooperację i konsens, oparte na działaniu komunikacyjnym. Habermas zajmuje się znalezieniem podstaw dla nowoczesnej, zróżnicowanej formy solidarności. Jest to dla niego problem będący kwestią integracji społecznej, w której procesie dużą rolę odgrywa prawo karne i cywilne. Pojęcie działania komunikacyjnego jest u Habermasa

11 Por. D. Dobrzański, Zasada solidarności..., dz. cyt., s. 190.

12 J. Habermas, Teoria dziatania komunikacyjnego, t. 1..., dz. cyt., s. 364 .

13 Por. D. Dobrzański, Zasada solidarności..., dz. cyt., s. 207.

14 Por. D. Dobrzański, Zasada solidarności..., dz. cyt., s. 211.

15 Por. D. Dobrzański, Zasada solidarności..., dz. cyt., s. 191. 
kluczowe w tej sprawie, gdyż ma wyjaśnić, jak współcześnie w społeczeństwie tworzy się indywidualna tożsamość. Jego uwaga koncentruje się wokół indywiduacji i roli komunikacji w projektowaniu indywidualnej podmiotowości. Według niego tożsamość dojrzała jest zdolnością nadawania ciągłości własnej biografii. W przekonaniu Habermasa indywidualność jest własnym osiągnięciem podmiotu ${ }^{16}$.

Autor Teorii działania komunikacyjnego uważa, że momentem założycielskim paradygmatu intersubiektywistycznego $\mathrm{w}$ antropologii filozoficznej jest na przykład wprowadzenie rozumienia podmiotowości opartej na komunikacji w psychologii społecznej Meada ${ }^{17}$. Podmiotowość jest tu rozumiana jako uczestnicząca w komunikacji, a nie jako wewnętrzna przestrzeń samoświadomości wypełniona własnymi przedstawieniami i dostępna za pomocą introspekcji. Wedle Habermasa podejście to eliminuje obiektywizujące nastawienie obserwatora, zastępując je performatywnym nastawieniem uczestnika interakcji. Idealna wspólnota komunikacyjna zapewnia - jego zdaniem - racjonalny ideał kształtowania woli oraz warunki dla niczym nieskrępowanego prezentowania siebie ${ }^{18}$. Performatywne nastawienie uczestnika interakcji polega na tym, że podmioty działania komunikacyjnego przyjmują postawę akceptującą bądź odrzucającą proponowane przez siebie w akcie mowy propozycje. Dotyczy ono sytuacji, w której podmiot przechodzi z roli obserwatora do roli mówiącego oraz słuchającego, ucząc się postrzegać siebie jako „alter ego swojego alter ego". Treści normatywnych, które w paradygmacie świadomościowym były związane z rozumnym samoświadomościowym podmiotem, teraz należy poszukiwać w tym normatywnym stosunku ego i alter, które podejmują działanie komunikacyjne. Indywidualna tożsamość jednostki i tożsamość społeczeństwa w nowym, intersubiektywnym paradygmacie ujmowane są jako nierozdzielne elementy ${ }^{19}$. Postawy na „tak” lub „nie” wobec przedstawionej przez rozmówcę propozycji ugruntowane są w schemacie poznawczym podmiot-przedmiot oraz odniesieniu normatywnym, gdyż przepełnione są roszczeniami, które konstytuują prawidłowy tok interakcji ${ }^{20}$.

16 Por. D. Dobrzański, Zasada solidarności..., dz. cyt., s. 191.

17 Por. D. Dobrzański, Zasada solidarności..., dz. cyt., s. 197.

18 Por. D. Dobrzański, Zasada solidarności..., dz. cyt., s. 198.

19 Por. D. Dobrzański, Zasada solidarności..., dz. cyt., s. 198.

20 Jak zauważa Dobrzański, Habermas wymienia cztery uniwersalne roszczenia ważnościowe, które wysuwają względem siebie rozmówcy: 1. Zrozumiałości wypowiedzi (przestrzegania podstawowych reguł używania języka); 2. Adekwatności jej części propozycjonalnej; 3. Słuszności lub 
Można powiedzieć, że dla Habermasa milcząco zakładaną przez podmioty wiedzą użycia języka, a równocześnie zasobem i kontekstem działań komunikacyjnych, jest „komunikacyjny świat życia” ${ }^{21}$. Habermas opiera swe analizy świata życia na badaniach fenomenologicznych Alfreda Schutza, poszerzając je o kategorie perspektywy narratora ${ }^{22}$. Komunikacyjny świat życie cechują trzy momenty: nastawienie na porozumienie, oparcie działań komunikacyjnych na sprawdzonych więziach solidarności i kompetencji oraz wyrażająca się w praktykach narracyjnych „totalność”, „nieokreśloność”23. Dodatkowo komunikacyjny świat życia, przez który Habermas rozumie społeczeństwo, wyrasta z trzech podstawowych idealizacji: przejrzystości komunikacji, niezależności kultury i autonomii działających ${ }^{24}$. Jak zauważa Magdalena Żardecka-Nowak, według Habermasa do rewitalizacji świata życia przyczyni się usuwanie zakłóceń komunikacyjnych. Niemiecki filozof stworzył koncepcję niezakłóconej komunikacji, idealnej sytuacji rozmowy, w której aktorzy poszukujący wspólnej wiedzy kulturowej i racjonalnie motywowanej zgody oraz wspólnych definicji tworzą indywidualne tożsamości i budują solidarność wspólnotową ${ }^{25}$.

Według Habermasa - w związku z przemianami historycznymi i zmianą paradygmatu - filozofia w XXI wieku ma być praktyczna. Przypada jej rola interpretatora mediującego między kulturą ekspertów a członkami codziennej praktyki, którzy potrzebują długofalowych planów ${ }^{26}$. Funkcją filozofii praktycznej, która pokazuje deformację życia codziennego przez wiedzę ekspercką, jest emancypacja. Epistemologia, filozofa moralna, filozofia społeczna czy inne subdyscypliny filozoficzne mają w tym kontekście stać się naukami rekonstrukcyjnymi, podejmującymi interpretację z punktu widzenia uczestników interakcji i dyskursów. Przenoszenie milcząco zakładanych kompetencji użytkowników na poziom teoretyczny, ich ukazywanie i opisywanie, składa się na racjonalną rekonstrukcję, która ma być głównym zajęciem nauk rekonstrukcyjnych. Ich interpretacyjny charakter

stosowności; 4. Prawdomówności mówiących. Por. D. Dobrzański, Zasada solidarności..., dz. cyt., s. 226.

21 Por. D. Dobrzański, Zasada solidarności..., dz. cyt., s. 202.

22 Por. D. Dobrzański, Zasada solidarności..., dz. cyt., s. 203.

23 Por. D. Dobrzański, Zasada solidarności..., dz. cyt., s. 203.

24 Por. D. Dobrzański, Zasada solidarności..., dz. cyt., s. 204.

25 Por. M. Żardecka-Nowak, Sfera publiczna jako przestrzeń swobodnej komunikacji-wokót koncepcji Jürgena Habermasa, w: Cechy - procesy - przebudowa. Przestrzeń publiczna we wspótczesnych systemach politycznych, red. W. Paruch, P. Maj, T. Koziełło, Rzeszów 2011, s. 58.

26 Por. D. Dobrzański, Zasada solidarności..., dz. cyt., s. 196. 
- w przeciwieństwie do hermeneutyki - zawiera roszczenie do uniwersalności ${ }^{27}$. Pomimo że racjonalne działania, moc argumentów i konieczność uzasadniania są związane $\mathrm{z}$ hipotetyzmem, przekraczają lokalne konteksty. Zdaniem Habermasa powiązanie dążenia do uniwersalizmu z hipotetyzmem może być traktowane jako nakaz rozumu pozbawionego oparcia $\mathrm{w}$ religijno-metafizycznym świecie i zróżnicowanych wartościach kultur. Habermas proponuje za uniwersalne postulaty przyjąć między innymi dyskurs jako procedurę oraz „zasadę uniwersalizacji”28.

Warto wspomnieć, że metodą, jaką posługuje się Habermas w swoich badaniach, jest odrywanie własnego wyjaśniania od kontekstu, teoretyzowanie i stosowanie idealizacji, będącej eksperymentem myślowym i niezbędnym składnikiem działania społecznego o charakterze refleksyjnym ${ }^{29}$. Racjonalność komunikacyjna obejmuje krytyczne, refleksyjne nastawienie wobec kontekstu. Habermas twierdzi, że wspólna płaszczyzna rozstrzygania sporów między racjonalizującymi się w świecie jednostkami a różnicującymi się systemami powinna być zbudowana na komunikacji, której ideałem jest „przyjmowanie postawy innego”, co ma m.in. walor poznawczy ${ }^{30}$. Ideał ten, będący także rodzajem testu, punkt wyjścia ma w dialogiczności sytuacji. Moralny punkt widzenia to dla Habermasa przyjęcie takiego stanowiska, z którego pytania moralne mogą być bezstronnie uzasadniane w wolnym nieskrępowanym dyskursie ${ }^{31}$. Dyskursem Habermas nazywa używanie kompetencji komunikacyjnej drugiego stopnia ${ }^{32}$. Poziom dyskursu to taka forma argumentacji, w której mówiący i słuchający tematyzują sporne roszczenia ważnościowe i próbują - za pomocą argumentów wyposażonych w racje - uznać je albo odrzucić. Habermas wyróżnia dyskurs teoretyczny, który dotyczy zdań przyporządkowanych obiektywnemu światu i prawdzie, oraz dyskurs praktyczny, dotyczący kwestii etycznych i moralnych. Dyskursy teoretyczne badają poprawność roszczeń na temat prawdy czy wyjaśniania, używając tych samych idealizacyjnych, refleksyjnych założeń i zawieszając kontekstualne właściwości działania ${ }^{33}$. Dyskursy praktyczne dotyczą zasad, norm, wartości, które zakładane są wspólnie w interakcjach. Jeśli dyskurs

\footnotetext{
27 Por. D. Dobrzański, Zasada solidarności..., dz. cyt., s. 197.

28 Por. D. Dobrzański, Zasada solidarności..., dz. cyt., s. 197.

29 Por. D. Dobrzański, Zasada solidarności..., dz. cyt., s. 199.

30 Por. D. Dobrzański, Zasada solidarności..., dz. cyt., s. 202.

31 Por. D. Dobrzański, Zasada solidarności..., dz. cyt., s. 224.

32 Por. D. Dobrzański, Zasada solidarności..., dz. cyt., s. 224.

33 Por. D. Dobrzański, Zasada solidarności..., dz. cyt., s. 232.
} 
praktyczny spełnia pewne warunki, jest dyskursem racjonalnym, czyli procedurą argumentowania, w której o rozstrzygnięciu sporu decyduje siła argumentów, a nie argument siły ${ }^{34}$. Jego celem jest konsensus uczestników co do rezultatów. Według Habermasa solidarność wytworzona jest w ramach integracji społecznej przez działanie komunikacyjne, które w aspekcie dochodzenia do porozumienia pełni także funkcję służenia tradycji oraz reprodukcji wzorów kulturowych, a także wykształcenia indywidualnych tożsamości w kwestii socjalizacji. Koncepcja komunikacyjnej solidarności składa się z koncepcji dyskursu oraz mechanizmu "przyjmowania perspektyw”35.

Habermasowska teoria racjonalności i racjonalnego działania umożliwia pokazanie, w jaki sposób wiedza społeczna używana jest dyskursywnie - przez dodanie czynnika refleksyjnego ${ }^{36}$. Habermas wyjaśnia społeczne działania za pomocą współdzielonej wiedzy i rozumienia. Jego analizy nie są indywidualistyczne, lecz społeczne. Intencjonalne działania wyjaśnia on poprzez odniesienie do czegoś więcej niż subiektywnych przekonań i pragnień. Wyjaśnienia działania wobec innego człowieka muszą, jego zdaniem, odwoływać się zarówno do wyrażanych w prost powodów, jak i implicytywnych przesłanek i poglądów, aby uzasadnić konkretne działanie. Kontekst działania tworzą implicytywne założenia, badane i ukazywane przez teorie. Jak twierdzi Habermas, odróżnienie między dyskursywnym powodem wyrażanym explicite a implicytywnym „światem życia” jest konieczne ${ }^{37}$.

Max Pensky zauważa, że punktem wyjścia Habermasa w Teorii działania komunikacyjnego jest teza, iż nowoczesne społeczeństwo pojęte jako historycznie ewoluujący system podlega procesom ustawicznej dyferencjacji, pojmowane natomiast jako świat życia ulega racjonalizacji oznaczającej brak oparcia w tradycji „metafizycznego myślenia”38. Społeczna solidarność nie wynika już z normatywnego konsensusu świata życia. Uczestnicy świata życia muszą współcześnie liczyć na własne umiejętności komunikacyjne, racjonalne uzasadnianie swoich działań i rozumienie działań rozmówców. Codzienne sytuacje wymagają używania argumentów oraz rozróżniania między normatywną poprawnością, prawdziwością, subiektywną autentycznością a wyjaśnianiem obiektywnym do rozwiązywania problemów. 
Intersubiektywne porozumienie może zostać osiągnięte tylko dzięki dyskursywnym środkom rozwiązywania problemów, wprowadzającym symetrię oraz wzajemność. Zdaniem Pensky'ego skromna koncepcja racjonalności komunikacyjnej Habermasa może skutecznie pośredniczyć między unifikującym roszczeniem rozumu a kwestionującą je ideą przypadkowości. Normatywna koncepcja świata społecznego, z którym jesteśmy połączeni poprzez formalne struktury słuchania i mówienia, jest zagwarantowana przez ufundowany w tych strukturach codziennej komunikacji rozum. Solidarność można streścić jako akty inkluzji przenoszone - poprzez uczucia, nastawienie osób i polityczne instytucje - z podstawowej lingwistycznej kompetencji w etos demokratycznych form życia społecznego ${ }^{39}$. Innymi słowy, jest ona komunikacyjną udaną integracją społeczną, która łączy system i świat życia. Zdaniem Pensky’ego koncepcja solidarności u Habermasa jest wątkiem jego filozofii praktycznej łączącym proponowaną przezeń koncepcję teorii działania komunikacyjnego i filozofię prawa. Według niego koncepcja solidarności pozwala odnaleźć w tekstach Habermasa spójność i ciągłość oraz połączyć jego teorię dyskursu z rozległym obszarem debat etycznych i politycznych ${ }^{40}$.

Kluczowe pytanie, jakie pojawia się w związku z kwestią solidarności, dotyczy tego, jak pogodzić sprawiedliwość z życzliwością ${ }^{41}$. Habermas podkreśla, że bez nieograniczonej wolności indywidualnej, by przyjmować normatywne roszczenia ważnościowe, żadne osiągnięte porozumienie nie może być naprawdę uniwersalne, a bez pochodzącej z solidarności empatii dla wszystkich - znajdujących się w danej sytuacji - żadna decyzja umożliwiająca konsensus nie może zostać podjęta ${ }^{42}$. Według Habermasa należy zrezygnować z indywidualistycznej perspektywy, która oddziela od siebie pojęcia sprawiedliwości oraz życzliwości, i przyjąć perspektywę realistyczną, interakcjonistyczną bądź dialogiczną ${ }^{43}$. Wówczas wyjdzie na jaw, że zasada równego szacunku zostaje powiązana z solidarnością, a nie z życzliwością. Solidarność jako zasada zostaje wtedy ugruntowana w przekonaniu, że każdy jako osoba musi wziąć odpowiedzialność za drugą osobę, gdyż zachowanie

39 Por. M. Pensky, The End of Solidarity..., dz. cyt., s. IX.

40 Por. M. Pensky, The End of Solidarity..., dz. cyt., s. XI.

41 Por. J. Habermas, Justice and Solidarity: On the Discussion Concerning stage 6, w: The Moral Domain: Essays in the Ongoing Discussion Between Philosophy and the Social Science, ed. T. E. Wren, Cambridge 1990, s. 224-251.

42 Por. Por. J. Habermas, Justice and Solidarity..., dz. cyt., s. 246.

43 Por. D. Dobrzański, Zasada solidarności..., dz. cyt., s. 222. 
integralności tożsamości jest naszym wspólnym interesem. Zdaniem Habermasa deontologiczna sprawiedliwość potrzebuje solidarności jako rewersu. Solidarność indywidualnych członków wspólnoty, w której są socjalizowani, jest wymagana, aby zabezpieczyć intersubiektywne związki wzajemnego uznania. Jej zadaniem jest troska o dobro członków wspólnoty. Sprawiedliwość natomiast dba o taką samą wolność dla poszczególnych osób. Ponadto solidarność gwarantuje utrzymanie integralności wspólnych form życia. Normy moralne muszą zabezpieczyć zarazem równe prawa i wolności dla jednostki, jak i dobra wszystkich członków wspólnoty. Solidarność, aby mogła stać się drugą stroną sprawiedliwości, musi zrzucić balast normatywności zakorzenionej w partykularnym świecie życia ${ }^{44}$.

Dobrzański zwraca uwagę na to, że Habermas pozyskał koncept połączenia sprawiedliwości z solidarnością w wymiarze etycznym i społecznym z rozważań nad tradycją judeochrześcijańską, w której normatywność związaną z Chrystusem oraz drogą zbawienia, wyznaczoną znakami „naśladowania Chrystusa”, ustanawia Bóg osobowy ${ }^{45}$. Według Habermasa każda osoba ma dwojakie komunikacyjne odniesienie do Boga: jako jeden ze wspólnoty wiernych oraz jako niezastępowalna jednostka. Zapośredniczone przez Boga moralne odniesienie do drugiej osoby z perspektywy solidarności i sprawiedliwości naznaczone jest strukturą komunikacyjną. Więź solidarności wiąże członków uniwersalnej wspólnoty wiernych. Sprawiedliwość natomiast wynika z niezastępowalności każdej jednostki i wynikającego z niej szacunku. Zgodnie z tradycją judeochrześcijańską solidarność i sprawiedliwość to dwa aspekty tej samej sprawy, które ujmują strukturę komunikacyjną z różnych punktów widzenia ${ }^{46}$. Żardecka-Nowak zwraca uwagę na to, że - według Habermasa - gdy pytamy o definicję sprawiedliwości lub solidarności, znaczenie ma głos wspólnot interpretacyjnych, jakimi są kościoły jako elementy społeczeństwa obywatelskiego i spadkobiercy dziedzictwa kulturowego, do którego świeckie społeczeństwo nie miałoby bez nich dostępu ${ }^{47}$. Habermas zaznacza, że solidarność wymaga zwracania się do religijnych członków społeczeństwa jako do równych członkom świeckim. Państwo powinno być według niego świeckie, ale nie społeczeństwo. Niemiecki filozof był przekonany,

44 Por. D. Dobrzański, Zasada solidarności..., dz. cyt., s. 223.

45 Por. D. Dobrzański, Zasada solidarności..., dz. cyt., s. 224.

46 Por. D. Dobrzański, Zasada solidarności..., dz. cyt., s. 224.

47 Por. M.Żardecka-Nowak, Sfera publicznajako przestrzeń swobodnej komunikacji-wokót koncepcji Jürgena Habermasa..., dz. cyt., s. 65. 
że przyznając większą rolę religii w społeczeństwie, wzbogaca projekt oświeceniowy i konsekwentnie afirmuje zasady wolności i solidarności ${ }^{48}$.

Habermasowski projekt etyki dyskursu - podkreślający rolę solidarności - poszukuje perspektywy łączącej uniwersalizm zasad z partykularnością dobra ${ }^{49}$. Kantowski imperatyw kategoryczny, będący wzorem dla Habermasa, staje się u niego procedurą moralnej argumentacji o charakterze dialogicznym. Moralności mają według Habermasa dwie zasady: sprawiedliwości i solidarności. Zasada sprawiedliwości postuluje równe prawa i szacunek, a zasada solidarności empatię jako gotowość „przyjęcia postawy innego” i troskę o pomyślność podzielających ten sam „świat życia” członków wspólnoty. Najważniejsze zasady etyki dyskursu to natomiast „zasada dyskursu”, która głosi, że „tylko takie normy mogą mieć roszczenia do obowiązywania, które mogłyby znaleźć zgodę wszystkich zainteresowanych jako uczestników praktycznych dyskursów" ${ }^{50}$, jak również „zasada uniwersalizacji”, która głosi, iż „dana norma obowiązuje dokładnie wtedy, gdy przewidywane następstwa i skutki uboczne, które przypuszczalnie wynikną z jej powszechnego przestrzegania dla interesów i orientacji każdego z osobna, mogłyby być w sposób wolny od przymusu wspólnie zaakceptowane przez wszystkich"51.

Rdzeń solidarności u Habermasa konstytuują dwa elementy, które wraz z elementem odnoszącym się do rdzenia sprawiedliwości (podkreślenie, że nikt z uczestników nie może być zmuszany do odpowiedzi twierdzącej) składają się na etykę dyskursu pojęcia racjonalnego konsensusu ${ }^{52}$. Po pierwsze przekonywanie wymaga znajomości słownika osoby przekonywanej. Po drugie zainteresowanie „powszechnością” strukturalizuje współpracę. Innymi słowy, związek między empatyczną troską o dobro jednostek a sprawiedliwością normatywnej grupowej kooperacji jest w solidarności nierozerwalny. Warto zauważyć, że w ujęciu Habermasa jednostki muszą posiadać kognitywne umiejętności do abstrakcyjnej refleksji oraz konceptualizacji świata w ogólnych terminach, aby działać solidarnie.

Drugi z omawianych filozofów, Rorty, przekonuje, że solidarność jest moralną zasadą, którą należy kreować. Jego projekt moralnej solidarności

48 Por. M. Żardecka-Nowak, Sfera publicznajako przestrzeń swobodnej komunikacji..., dz. cyt., s. 66.

49 Por. D. Dobrzański, Zasada solidarności..., dz. cyt., s. 232.

50 J. Habermas, Uwzględniając innego. Studia do teorii politycznej, tłum. A. Romaniuk, Warszawa 2009 , s. 46.

51 J. Habermas, Uwzględniając innego..., dz. cyt., s. 54 .

52 Por. D. Dobrzański, Zasada solidarności..., dz. cyt., s. 244. 
zakotwiczony jest w liberalnych społeczeństwach demokratycznych ${ }^{53}$. Habermas, posługujący się zasadą uniwersalizacji w etyce, jest przez Rorty'ego krytykowany podobnie jak wszyscy filozofowie, którzy normatywność uzasadniają, odwołując się do „rdzennej tożsamości” lub wewnętrznej „ludzkiej natury" ${ }^{24}$. Marcin Kilanowski zauważa, że Rorty myli się, uważając, że Habermas poszukuje czegoś uniwersalnie ludzkiego we wnętrzu istot ludzkich. Niemiecki filozof wprawdzie pisze o bezwarunkowości i uniwersalności, ale nie w kontekście wspierania idei ahistorycznej natury człowieka, lecz w kontekście niezbędnych dla możliwości komunikacji jej warunków formalnych ${ }^{55}$.

Autor Przygodności, ironii i solidarności w prowadza podział na to, co prywatne i to, co publiczne jako pragmatyczne narzędzie pomocne przy unikaniu konfliktów między jednostką a społeczeństwem. Sfera prywatna to obszar autokreacjii autonomii podmiotu, w którym dużą rolę odgrywa ironia natomiast sfera publiczna związana jest ze sprawiedliwością proceduralną i solidarnością ${ }^{56}$.

Rozumienie ironii Rorty'ego różni się od rozumienia potocznego ${ }^{57}$. Zadaniem ironii, według niego, nie jest zranienie czy urażenie kogoś, szyderstwo ani doprowadzenie do cynizmu, lecz rozwinięcie wrażliwości etycznej, obrona przed dogmatyzmem i „monopolizmem” jakiegoś języka finalnego. $\mathrm{Z}$ tego punktu widzenia solidarność ma podobne zadanie, gdyż rozszerzanie jej zakresu prowadzić ma do postępu moralnego. Dlatego zasadne wydaje się nazwanie solidarności u Rorty'ego ironiczną w doprecyzowanym przezeń sensie.

Rorty ironistami nazywa ludzi, którzy mając skłonność do filozofowania, wygrywają to, co nowe przeciwko staremu. Zaznacza on, że ironiści nie dokonują wyboru między słownikami w ramach uniwersalnego metasłownika, ani nie próbują dotrzeć do rzeczywistości przysłoniętej zjawiskami. Rorty pisze, że nazywa ich „ironistami”, gdyż „świadomość, że poprzez nowy opis sprawić można, iż każda rzecz będzie wyglądać dobrze bądź źle, oraz wyrzeczenie się prób sformułowania kryteriów wyboru pomiędzy finalnymi słownikami stawia ich w pozycji, którą Sartre nazwał «meta-stabilną»: nigdy nie są do końca w stanie traktować siebie poważnie, cały czas mają bowiem

53 Zob. R. Rorty, Przygodność, ironia i solidarność, Warszawa 2009.

54 Por. D. Dobrzański, Zasada solidarności..., dz. cyt., s. 246.

55 Por. M. Kilanowski, Ku wolności jako odpowiedzialności. Dewey, Rorty, Habermas o nowej jakości $w$ demokracji, Toruń 2013, s. 224.

56 Por. M. Kilanowski, Ku wolnościjako odpowiedzialności..., dz. cyt., s. 104.

57 Por. A. Szahaj, Ironia i miłość. Neopragmatyzm Richarda Rorty'ego w kontekście sporu o postmodernizm, Toruń 2012, s. 92. 
świadomość, że słowa, za pomocą których opisują siebie, podlegają zmianie, stale pamiętają o przygodności i kruchości swych finalnych słowników, a przeto i swoich jaźni”" ${ }^{\text {". }}$. Zdaniem Rorty'ego myślicielem, który zapoczątkował tradycję filozofii ironicznej, był młody Hegel, a jego kontynuatorami Nietzsche, Heidegger i Derrida. Filozofowie Ci określają swój dorobek nie poprzez stosunek do prawdy, lecz do poprzedników ${ }^{59}$.

Rorty twierdzi, że przeciwieństwem postawy ironisty jest postawa kierującego się zdrowym rozsądkiem metafizyka, który bagatelizuje niezliczone przykłady ludzkiego cierpienia, traktując je jako nieistotne w porównaniu z tym, co wieczne i naprawdę ważne. Według ironisty teorie filozoficzne odnoszą się do obszaru prywatności, stanowiąc środek do rozwijania własnego „ja” ${ }^{\prime 0}$. Autokreacja to dla Rorty'ego jedyny możliwy pożytek, jaki może przynieść filozofia. W przeciwieństwie do Habermasa, amerykański pragmatysta nie sądzi, iżby teorie filozoficznie miały się przydać w polityce, ani że miarą ich wartości są płynące zeń konsekwencje polityczne czy społeczne.

Ironista pragnie uciec od przeszłości i tradycji, wciąż na nowo ją opisując. Największym wyzwaniem i pretekstem do samorealizacji są dla ironisty dzieła filozoficzne, które na nowo przepisuje, zastępując odziedziczone przygodności własnymi. Ironiczność solidarności można więc rozumieć jako jej przygodność. Nie jest to solidarność opierająca się na autorytecie przeszłości czy przyszłości. Dziś solidaryzuję się z tym, jutro z tamtym, w zależności od tego, jak silne uczucia kierują moją identyfikacją z daną osobą bądź osobami. Można odnieść wrażenie, że rządzi tym czysty przypadek, spod władzy którego ironista nie chce się wyzwolić, ale którym chce posłużyć się do tworzenia siebie. Jedynym sędzią ocen moralnych ironisty jest on sam. Ironisty bowiem nie interesuje to, jak prezentuje się on światu, lecz jak prezentuje się sobie. Dla ironisty nie ma nic ważniejszego poza własnym „ja”, które opisuje. Dokonania ironisty zrelatywizowane są do czasu, miejsca i sytuacji, a jego definicji nie sposób sformułować ${ }^{61}$.

W ujęciu Rorty'ego przekonania światopoglądowe powinny zostać prywatną sprawą jednostki ${ }^{62}$. Jego zdaniem powinniśmy tworzyć utopijne projekty społeczne, ale nie wcielać ich w życie. W sferze publicznej musimy

58 R. Rorty, Przygodność, ironia i solidarność, Warszawa 2009, s. 123.

59 Por. R. Rorty, Przygodność, ironia i solidarność..., dz. cyt., s. 130.

6o Por. M. Żardecka-Nowak, Wspólnota i ironia. Richard Rorty ijego wizja spoteczeństwa liberalnego, Lublin 2003, s. 241.

61 Por. M. Żardecka-Nowak, Wspólnota i ironia..., dz. cyt., s. 245.

62 Por. A. Szahaj, Ironia i mitość..., s. 90. 
kierować się pragmatycznymi kryteriami użyteczności. Według niego konieczne jest wprowadzanie reform społecznych oraz stałe ulepszanie mechanizmów demokracji liberalnej. Nie mają one żadnego z góry określonego celu, ale na nich opierają się demokratyczne mechanizmy ustanawiania woli powszechnej, które korzystają z perswazji, a nie z przemocy. Stąd ironista powściągliwie zachowuje się w stosunku do tradycji politycznej i społecznej. Nie ma zamiaru realizować własnej utopijnej wizji społeczeństwa, gdyż ma świadomość, że przekraczanie siebie i autokreacja są dobrym celem dla jednostki, ale nie dla społeczeństwa.

Według Rorty’ego solidarność jest utopijnym celem, przedmiotem wyobraźni, a nie faktem, który można odkryć. Jej moc zależy od tego, które podobieństwa i różnice z innymi uznajemy za znaczące. Rorty uważa, że nasze poczucie solidarności jest silniejsze, kiedy tych, wobec których okazujemy solidarność, uznaje się za „jednych z nas”, przy czym „my” to grupa węższa i bardziej lokalna aniżeli gatunek ludzki. Według niego solidarność to „zdolność do postrzegania coraz większej liczby dawnych różnic (plemiennych, religijnych, rasowych, obyczajowych i tym podobnych) jako nieistotnych w porównaniu z podobieństwami, gdy chodzi o cierpienie i upokorzenie zdolność do myślenia o osobach zdecydowanie różniących się od nas jako objętych zasięgiem «my»" ${ }^{63}$. Rorty proponuje jednocześnie, aby rozciągnąć nasze rozumienie „my” na osoby, które wcześniej uważaliśmy za „ich”. Propozycja ta, charakterystyczna dla liberałów, czyli ludzi, którzy bardziej niż czegokolwiek innego obawiają się bycia okrutnymi, nie znajduje oparcia w niczym głębszym aniżeli historyczne przygodności. Są to przygodności, które dały początek rozwojowi słownika moralnego i politycznego - typowego dla świeckich społeczeństwach demokratycznych Zachodu.

Rorty twierdzi, że głównym wkładem współczesnych intelektualistów w postęp moralny są szczegółowe opisy konkretnych, różnorodnych przypadków cierpienia i upokorzenia zawarte np. w powieściach lub pracach etnograficznych, a nie filozoficzne czy religijne traktaty. Sądzi on, że Kant myli się, uważając, że sposobem na rozwój instytucji demokratycznych i kosmopolitycznej świadomości politycznej jest wysuwanie na pierwszy plan nie litości dla cierpienia i wyrzutów związanych z okrucieństwem, lecz racjonalności i moralnej powinności. Zdaniem Rorty’ego Kant nie ma racji, gdy twierdzi, że szacunek dla „rozumu”, powszechnego rdzenia człowieczeństwa, jest

63 R. Rorty, Przygodność, ironia i solidarność, dz. cyt., s. 293. 
jedyną pobudką, która nie zależy od przypadkowości zainteresowania czy historii. Rorty obwinia Kanta za to, że przeciwstawiając racjonalny szacunek uczuciom litości i wielkoduszności, sprawił, że te ostatnie wydały się wątpliwymi i drugorzędnymi pobudkami ku temu, by nie być okrutnym. Kant uczynił tym samym „moralność” czymś odrębnym od zdolności zauważania bólu i upokorzenia oraz utożsamiania się z nimi.

Dla Rorty'ego wzorem do naśladowania jest zmierzająca w kierunku niewymuszonego porozumienia tolerancyjna wspólnota naukowców. Instytucje i organizacje stworzone przez nich powinny być modelem dla innych środowisk. Rorty uważa, że spoiwem integrującym wspólnotę jest wolna dyskusja, a organizacje społeczne mają za zadanie stworzenie warunków do samorealizacji jednostek. Amerykański pragmatysta krytykuje Habermasa za to, że koncepcję solidarności opiera na uniwersalistycznych zasadach i nie chce być ironistą, lecz liberalistą. Rorty'emu utożsamienie się z ludzkością jako taką wydaje się wymysłem filozofów i nieudanym zabiegiem zeświecczenia idei zjednoczenia $z$ Bogiem.

Ostrą krytykę stanowiska Rorty'ego przedstawia natomiast Norman Ge$\operatorname{ras}^{64}$. Zakwestionowanie uzasadnienia, które odwołuje się do uniwersalności, powoduje brak podstaw dla twierdzenia Rorty'ego, że najgorszą rzeczą, jakiej mogą dopuścić się liberałowie, jest okrucieństwo.

Interesującą interpretację Rortiańskiego rozumienia solidarności przedstawia Szahaj, który określa ją jako solidarność negatywną, nawiązując do rozróżnienia Isaiaha Berlina na wolność pozytywną i negatywną ${ }^{65}$. Oznacza to, że jest to solidarność, której motywem nie jest dążenie do z góry wyznaczonych celów, lecz unikanie czegoś, w tym przypadku cierpienia i poniżenia. Szahaj uważa, że uwolnienie pojęcia solidarności od metafizycznych podstaw, uczynienie jej sytuacyjną i wsparcie na przesłankach etnocentrycznych jest słuszne. Dostrzega jednak, że pozbawienie pojęcia solidarności metafizycznych założeń samo jest metafizycznym założeniem. Sprzeciwianie się cierpieniu czy poniżeniu innego człowieka zakłada brak zgody na urąganie ludzkiej godności, więc uznanie jej za wartość.

Spór filozoficzny między uniwersalistycznym a etnocentrycznym uzasadnieniem solidarności jest dyskusją o ogólnych zasadach, do których człowiek solidarny może odwołać się przy uzasadnianiu swoich działań. Wybór jest

64 Zob. N. Geras, Solidarity in the Conversations of Mankind, London 1995, s. 47-71.

65 Por. A. Szahaj, Ironia i miłość..., dz. cyt., s. 89. 
między powoływaniem się na światopogląd bądź religię a odwoływaniem się do codziennej praktyki.

Mimo że Rorty i Habermas inaczej uzasadniają solidarność, jest również coś, co ich łączy. Tym czymś jest przywiązywanie wagi do „kultury praw człowieka" ${ }^{66}$. Oznacza ona dla nich argument na rzecz postępu moralnego oraz oręż w kształtowaniu opinii publicznej, mające na celu opór wobec okrucieństwa. Obaj myśliciele uznają solidarność za pewien konwencjonalny sposób radzenia sobie $\mathrm{z}$ konfliktami w docieraniu do porozumienia, $\mathrm{z}$ tą różnicą, że Habermas jako sposób uprawiania solidarności wybiera budowanie teoretycznej aparatury, a Rorty stawia na pobudzanie wyobraźni czytelników i uwrażliwianie ich dzięki literaturze. Odmienność ta wydaje się mało istotna $\mathrm{w}$ porównaniu $\mathrm{z}$ podzielanym przez nich pragnieniem budowania otwartej i solidarnej wspólnoty.

\section{Bibliografia}

Dobrzański D., Zasada solidarności. Studium z filozofi społecznej, WN UAM, Poznań 2013.

Geras N., Solidarity in the Conversations of Mankind, Verso, London 1995.

Habermas J., Justice and Solidarity: On the Discussion Concerning "Stage 6", w: The Moral Domain: Essays in the Ongoing Discussion Between Philosophy and the Social Science, ed. T. E. Wren, The MIT Press, Cambridge 1990, s. 224-251.

Habermas J., Teoria dziatania komunikacyjnego, t. 1: Racjonalność dziatania a racjonalność spoteczna, tłum. A. M. Kaniowski, PWN, Warszawa 1999.

Habermas J., Teoria dziatania komunikacyjnego, t. 2: Przyczynek do krytyki rozumu funkcjonalnego, tłum. A. M. Kaniowski, PWN, Warszawa 2002.

Habermas J., Uwzględniając innego. Studia do teorii politycznej, tłum. A. Romaniuk, PWN, Warszawa 2009.

Kilanowski M., Ku wolności jako odpowiedzialności. Dewey, Rorty, Habermas o nowej jakości w demokracji, WN UMK, Torun 2013.

Pensky M., The End of Solidarity. Discourse Theory in Ethics and Politics, State University of New York Press, New York 2008.

Rorty R., Human Rights, Rationality, and Sentimentality, w: On Human Rights. The Oxford Amnesty Lectures 1993, red. S. Shute, S. Hurley, BasicBooks, New York 1993, s. 111-134.

66 Zob. R. Rorty, Human Rights, Rationality, and Sentimentality, w: On Human Rights. The Oxford Amnesty Lectures 1993, ed. S. Shute, S. Hurley, New York 1993, s. 111-134. 
Rorty R., Przygodność, ironia i solidarnosśc, tłum. W. J. Popowski, WAB, Warszawa 2009. Szahaj A., Ironia i mitość. Neopragmatyzm Richarda Rorty’ego w kontekście sporu o postmodernizm, WN UMK, Toruń 2012.

Żardecka-Nowak M., Sfera publiczna jako przestrzeń swobodnej komunikacji - wokót koncepcji Jürgena Habermasa, w: Cechy - procesy - przebudowa. Przestrzeń publiczna we wspótczesnych systemach politycznych, red. W. Paruch, P. Maj, T. Koziełło, WUR, Rzeszów 2011, s. 50-68.

Żardecka-Nowak M., Wspólnota i ironia. Richard Rorty i jego wizja społeczeństwa liberalnego, WKUL, Lublin 2003.

\section{Abstrakt}

Solidarność ironiczna i solidarność dyskursywna. Kilka uweag o miejscu solidarności w filozofi ispołecznej Richarda Rorty'ego i ürgena Habermasa

Kluczowym celem referatu jest odpowiedzieć na pytanie, jak Rorty i Habermas rozumieją solidarność oraz w jakim stosunku do siebie pozostają ich koncepcje solidarności. Solidarność u Habermasa może być rozumiana jako akty inkluzji, przenoszone z podstawowej lingwistycznej kompetencji i obecne ostatecznie w etosie demokratycznych form życia społecznego. Habermas rozumie solidarność jako udaną społeczną integrację, która łączy sferę świata życia oraz system. Dzięki solidarności można powiązać Habermasowską koncepcję teorii działania komunikacyjnego i filozofii prawa. Rorty natomiast zdaje się postrzegać solidarność jako niepewność, którą stopniowo w ciągu kilku ostatnich stuleci wpajano mieszkańcom państw demokratycznych. Niepewność co do własnej wrażliwości na cierpienie i upokorzenie innych, zwątpienie, czy aktualne rozwiązania instytucjonalne są odpowiednie do tego, by radzić sobie z tym cierpieniem i upokorzeniem, otwarcie na możliwe alternatywy. Rorty odróżnia tak rozumianą solidarność od solidarności jako utożsamienia się z ludzkością. Na pierwszy rzut oka podejścia filozofów wydają się antagonistyczne, ale może coś ich łączy, np. podobne spojrzenie na porozumienie, do którego dochodzi dzięki sile perswazji, a nie przemocy.

Słowa kluczowe

solidarność, integracja, dyskurs, działanie komunikacyjne, demokracja, ironia, uniwersalizm, etnocentryzm, porozumienie 